\title{
Nimotuzumab Inhibits Cholangiocarcinoma Cell Metastasis via Suppression of the Epithelial-Mesenchymal Transition Process
}

\author{
SUREERAT PADTHAISONG ${ }^{1,2}$, MALINEE THANEE ${ }^{1,2,3}$, ANCHALEE TECHASEN AN $^{2,3,4}$, \\ NISANA NAMWAT ${ }^{1,2,3}$, PUANGRAT YONGVANIT ${ }^{2,3}$, AEKKAPHOD LIWATTHAKUN $^{5}$, \\ KHITTISAK HANKLA ${ }^{5}$, SAKKARN SANGKHAMANON ${ }^{4,6}$ and WATCHARIN LOILOME ${ }^{1,2,3}$ \\ Departments of ${ }^{1}$ Biochemistry, ${ }^{5}$ Surgery, and ${ }^{6}$ Pathology, Khon Kaen University, Khon Kaen, Thailand; \\ ${ }^{2}$ Cholangiocarcinoma Research Institute, Faculty of Medicine, \\ ${ }^{3}$ Cholangiocarcinoma Screening and Care Program (CASCAP) and \\ ${ }^{4}$ Faculty of Associated Medical Sciences, Khon Kaen University, Khon Kaen, Thailand
}

\begin{abstract}
Background/Aim: Changes in epidermal growth factor receptor (EGFR) are commonly found in cancer progression, signaling a poor outcome in patients. In the present study, we aimed to investigate whether nimotuzumab could be of benefit for cholangiocarcinoma (CCA) treatment. Materials and Methods: The expression of EGFR was explored using immunohistochemical staining in cases divided into groups with low and high expression. The effect of nimotuzumab on CCA cell growth, metastasis and the molecular mechanisms by which nimotuzumab inhibits CCA cell metastasis were evaluated. Results: The expression of EGFR was high in 55\% of patients with CCA. This was significantly correlated with a shorter survival of patients. CCA cells treated with nimotuzumab showed inhibited cell growth. Moreover, nimotuzumab inhibited CCA cell metastasis via induction of E-cadherin and suppression of zinc finger protein SNAII (SNAIL1), vimentin and matrix metalloproteinase 9 (MMP9) expression. Conclusion: Nimotuzumab appears to inhibit cell metastasis via suppression of the epithelial-mesenchymal transition process. Therefore, nimotuzumab should be considered as a potential therapeutic agent against CCA.
\end{abstract}

Cholangiocarcinoma (CCA) is cancer of the bile duct with a very high incidence in Thailand, particularly in northeastern area, where it is associated with high prevalence of liver fluke infection (1). Chronic inflammation induced by the

Correspondence to: Associate Professor Watcharin Loilome, Department of Biochemistry, Faculty of Medicine, Khon Kaen University, 123 Mittraparp Road, Muang District, Khon Kaen 40002, Thailand. E-mail:watloi@yahoo.com

Key Words: EGFR, nimotuzumab, cholangiocarcinoma, Opisthorchis viverrini, EMT. liver fluke Opisthorchis viverrini is a major risk factor for the development of CCA in this area. CCA is difficult to diagnose at an early stage. Most patients receive treatment when the disease becomes advanced, leading to a poor prognosis as surgical resection, which is potentially curative for early-stage disease, is usually ineffective for advanced or late stages $(2,3)$. Therefore, new approaches involving targeted therapy are needed.

We previously reported that the expression of kinase A regulatory subunit I $\alpha$ (PRKAR1A) is involved in carcinogenesis of CCA (4). The expression of PRKAR1A was also increased in human CCA tissues and cell lines (5). Moreover, inhibition of PRKAR1A induced apoptosis as well as growth inhibition (6). Recently, our group demonstrated that multiple protein kinases are activated in CCA tissues and cell lines (7). These protein kinases are involved in several mechanisms, including growth, apoptosis and metastasis. Among them, epidermal growth factor receptor (EGFR) is highly activated in both CCA tissues and CCA cell lines. These findings have led us to focus more on protein kinases, especially on EGFR, as potential targets for therapy.

EGFR is a receptor tyrosine kinase that can activate many pathways, including the mitogen-activated protein kinase (MAPK), phosphoinositide 3-kinase (PI3K)/protein kinase B (AKT), signal transducer and activator of transcription (STAT) and phospholipase C (PLC) $\gamma$ pathways $(8,9)$. High expression of EGFR has been reported in many cancer types, including glioma, head and neck, breast, cervical, renal cell and esophageal, as well as CCA. It is usually associated with a poor prognosis (10-19).

Nimotuzumab (h-R3) is a humanized recombinant IgG1 that is produced by recombination of the complementarity determining regions of R3 monoclonal antibody into human $I g G l$ gene (20). The efficacy of nimotuzumab has been reported in several cancers, including glioma $(21,22)$, oral squamous cell carcinoma (23), non-small cell lung cancer 
(24). Nowadays, nimotuzumab has been approved for cancer treatment, including glioma, head and neck squamous cell carcinoma, esophageal, pediatric and nasopharyngeal cancers (25), in several different countries. However, the effect of nimotuzumab on CCA is still unknown.

In the present study, we aimed to investigate whether nimotuzumab could inhibit CCA progression and has any benefit for therapy of CCA.

\section{Materials and Methods}

Human CCA tissues. Human CCA tissues were collected from patients with CCA who were admitted to Srinagarind Hospital, Khon Kaen University, Thailand, and were kept by the Cholangiocarcinoma Research Institute, Faculty of Medicine, Khon Kaen University. Paraffin-embedded tissues were obtained from the Cholangiocarcinoma Research Institute. The study protocol was approved by the Ethics Committee for Human Research, Khon Kaen University (HE571283).

Cell lines and cell culture. Human CCA cell lines KKU-214 and KKU-213 were established from patients with CCA and obtained from the Japanese Collection of Research Bioresources Cell Bank, Osaka, Japan. These cell lines were cultured in Dulbecco's modified Eagle's medium (DMEM) (Gibco/BRL, Grand Island, NY, USA) supplemented with $10 \%$ fetal bovine serum $\left(\right.$ Gibco $^{\circledR}$, Invitrogen, Carlsbad CA, USA), 100 units $/ \mathrm{ml}$ penicillin and $100 \mu \mathrm{g} / \mathrm{ml}$ streptomycin at $37^{\circ} \mathrm{C}$ with $5 \% \mathrm{CO}_{2}$.

Antibodies. Antibodies used for this study included: mouse monoclonal antibodies to EGFR (\#ab110006) and vimentin (\#ab8069) from Abcam, Cambridge, UK; rabbit polyclonal antibody to p-AKT ${ }^{\text {ser473 }}$ (\#SAB4300042) and mouse monoclonal antibody to $\beta$-actin (\#5541) from Sigma-Aldrich, MO, USA; rabbit polyclonal antibodies to AKT (\#9272) and p38 (\#9212), rabbit monoclonal antibodies to p-p38 Thr180/Tyr182 (\#4511) and matrix metalloproteinase 9 (MMP9) (\#13667) from Cell Signaling Technology, Danvers, MA, USA; rabbit polyclonal antibody to zinc finger protein SNAI1 (SNAIL1) (\#sc-28199) from Santa Cruz Biotechnology, Dallas, TX, USA; mouse monoclonal antibody to Ecadherin (\#610182) from BD Transduction Laboratories, San Jose, CA, USA. Nimotuzumab was provided by Alliance Pharma Company Limited, Thailand.

Immunohistochemical staining and scoring. Immunohistochemical analysis was performed to investigate the expression of EGFR in human CCA tissues. Paraffin-embedded tissues were de-paraffinized and rehydrated stepwise with xylene followed by $100 \%, 90 \%, 80 \%$ and $70 \%$ ethanol. Antigen retrieval was performed using a microwave cooker with sodium citrate buffer $\mathrm{pH} 6$ for $10 \mathrm{~min}$. The sections were treated with $0.3 \%$ hydrogen peroxide and $10 \%$ skim milk to block endogenous hydrogen peroxide activity and nonspecific binding for $30 \mathrm{~min}$ each. The tissue sections were then incubated with anti-EGFR at $4^{\circ} \mathrm{C}$ overnight. The sections were then washed in phosphatebuffered saline (PBS) with $0.1 \%$ Tween 20 and incubated with secondary antibody DakoEnVision for $1 \mathrm{~h}$. Next, the signal was developed with a 3,3'diaminobenzidine tetrahydrochloride (DAB) substrate kit (Vector Laboratories, Inc., Burlingame, CA, USA) for $5 \mathrm{~min}$, then counterstained with Mayer's hematoxylin. Finally, the sections were dehydrated stepwise with $70 \%, 80 \%, 90 \%, 100 \%$ ethanol and xylene, and mounted with permount. The stained sections were the viewed under a microscope at a $\times 20$ power. The scoring system was based on the intensity and frequency of staining in tumoral areas. The intensity of EGFR expression was divided into four groups: 0 , negative; +1 , weak expression; +2 , moderate expression, and +3 , strong expression. The frequency of EGFR expression was also divided into four groups: 0 , negative; $+1,1-25 \%$; $+2,26-50 \% ;+3,>50 \%$. The scores were evaluated by multiplying the intensity and frequency of each case. The cases were then classified into two groups: score $<6$, low expression; and score $\geq 6$, high expression (26).

Growth-inhibition assay. A sulforhodamine B (SRB) assay was used to detect the effect of nimotuzumab. Briefly, KKU-214 and KKU213 CCA cells $\left(1.5 \times 10^{3}\right.$ cells in $200 \mu \mathrm{l}$ DMEM $)$ were seeded into 96-well plates and incubated at $37^{\circ} \mathrm{C}$ with $5 \% \mathrm{CO}_{2}$ overnight. The cells were then treated with different concentrations of nimotuzumab $(1.25,2.5,5,10$ and $20 \mu \mathrm{M})$ and incubated for 24, 48, 72 and $96 \mathrm{~h}$. Subsequently, $10 \%$ cold trichloroacetic acid was used to fix the cells for $1 \mathrm{~h}$ at $4^{\circ} \mathrm{C}$. Cells were then stained with $0.4 \% \mathrm{w} / \mathrm{v} \mathrm{SRB}$ in $1 \% \mathrm{v} / \mathrm{v}$ acetic acid for $45 \mathrm{~min}$. Excess dye was washed off with $1 \%$ acetic acid and the stained CCA cells were solubilized with $10 \mathrm{mM}$ unbuffered Tris-base. The absorbance was then measured with a microplate reader (Sunrise; TECAN Trading, AG, Switzerland) at $540 \mathrm{~nm}$.

Wound-healing assay. CCA cell lines $\left(1 \times 10^{5}\right.$ cells in $1 \mathrm{ml}$ DMEM) were seeded into 24 -well plates and incubated at $37^{\circ} \mathrm{C}$ in $5 \% \mathrm{CO}_{2}$ overnight or until the cells were more than $90 \%$ confluent. The cell monolayer was then scratched using a $200 \mu \mathrm{l}$ tip and debris removed by rinsing with DMEM. Cells were then incubated in control medium or medium containing nimotuzumab. Each condition was performed in duplicate wells. Microscopy was used and the results digitally photographed at 0,12 and $15 \mathrm{~h}$. The the wound area was measured on the images and the migratory ability was calculated as: migratory ability $=$ (area of original wound - area of wound during healing)/area of original wound.

Invasion assay. The cell invasion assay was performed using a Boyden chamber with insert chambers coated with Matrigel. Briefly, $300 \mu \mathrm{l}$ of serum-free DMEM was added to the insert chamber, while $500 \mu$ of complete DMEM was added to the lower chamber. The chamber was then incubated at room temperature for $1 \mathrm{~h}$. CCA cell lines $\left(20 \times 10^{4}\right.$ cells $\left./ \mathrm{ml}\right)$ were pre-treated with nimotuzumab at $37^{\circ} \mathrm{C}$ for $30 \mathrm{~min}$. Before seeding, $250 \mu \mathrm{l}$ of serum-free DMEM was removed from the insert chamber, then $200 \mu$ of incubated cells was seeded into the insert chamber. The chamber was incubated at $37^{\circ} \mathrm{C}$ for $24 \mathrm{~h}$. The insert chamber was then collected and the medium removed. Cells located on the filter were fixed with methanol for $1 \mathrm{~h}$. Next, the fixed cells were stained with hematoxylin overnight. Filters were then washed with PBS and dried before being cut and mounted on a slide. Finally, the mounted slides were observed under a microscope at $\times 20$ power. The invading cells were counted in at least six fields in each condition and the result was expressed as the average of invading cells per field.

Western blot analysis. Total protein $(20 \mu \mathrm{g})$ was loaded onto NuPage ${ }^{\circledR}$ Novex $10 \%$ Bis-Tris gels (Invitrogen, Carlsbad, CA, USA) and blotted onto polyvinylidene difluoride membranes (Bio- 
A

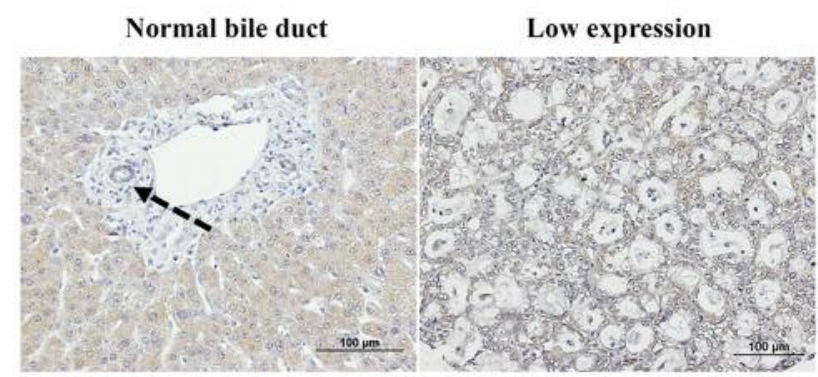

High expression

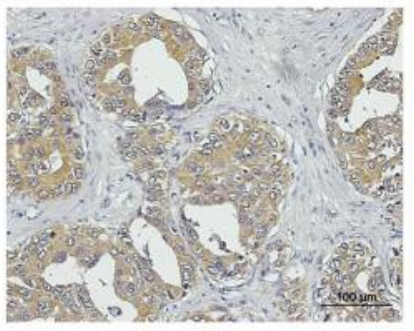

\section{B}

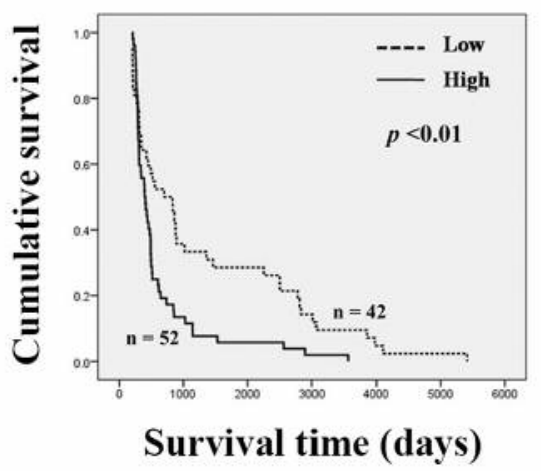

Figure 1. Expression of epidermal growth factor receptor (EGFR) in human cholangiocarcinoma tissues. A: Representative images of low and high EGFR expression. B: Survival analysis based on EGFR expression with time after surgery.

Rad Laboratories, Inc., Hercules, CA, USA). The membranes were blocked with $3 \%$ bovine serum albumin in Tris-buffered saline (TBS) at room temperature for $1 \mathrm{~h}$. The membranes were stained with primary antibodies described above at $4^{\circ} \mathrm{C}$ overnight. The membranes were then washed three times with TBS containing $0.1 \%$ Tween 20 followed by TBS for $5 \mathrm{~min}$ each. The membranes were then incubated with secondary antibody at room temperature for $1 \mathrm{~h}$ and subsequently washed as previously. Finally, the proteins were detected using chemiluminescent enhancment with an ECL Prime Western Blotting Detection System (GE Healthcare, Little Chalfont, UK). In this study, $\beta$-actin was used as an internal loading control.

Statistical analysis. Survival analysis was analyzed using the
A

KKU-214

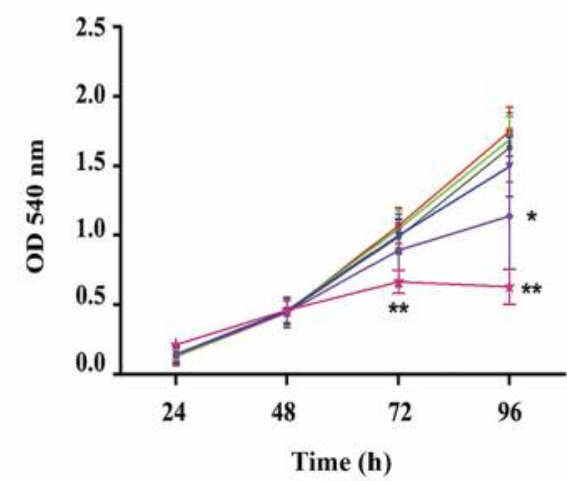

$\rightarrow 0 \quad \mu \mathrm{M}$

$\rightarrow 1.25 \mu \mathrm{M}$

$+2.5 \mu \mathrm{M}$

$\rightarrow 5 \mu \mathrm{M}$

$\rightarrow 10 \mu \mathrm{M}$

* $20 \mu \mathrm{M}$

B

KKU-213

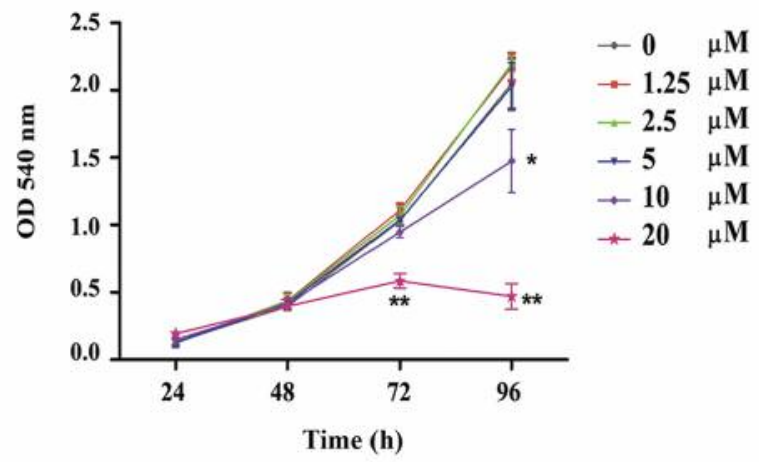

Figure 2. Growth-inhibitory effect of nimotuzumab on cholangiocarcinoma cell lines. KKU-214 (A) and KKU-213 (B) cells were treated with different concentrations of nimotuzumab for different durations. Growth inhibition was detected using the sulforhodamine B assay. Values of growth inhibition are shown using the absorbance (OD) of three independent experiments. Significantly different at $* p<0.05$ and $*^{* *}<0.01$ compared to the control by the Student's t-test.

Kaplan-Meier method using SPSS software version 17 (SPSS, Chicago, IL, USA). The results from the growth-inhibition assay, wound-healing assay and invasion assay are reported as the mean \pm SD and were analyzed using Student's $t$-test. A $p$-value of less than 0.05 was considered statistically significant.

\section{Results}

Patient characteristics. A total of 94 human CCA tissue samples were studied of which $62 \%$ were from males and $38 \%$ from females. The age of patients with CCA ranged between 33 to 76 years (median=55 years). The histological type was characterized as papillary $38 \%$ and non-papillary $62 \%$. All the patients in this study had an advance stage of the disease, with $49 \%$ having metastases.

High expression of EGFR predicts poor prognosis in patients 
A

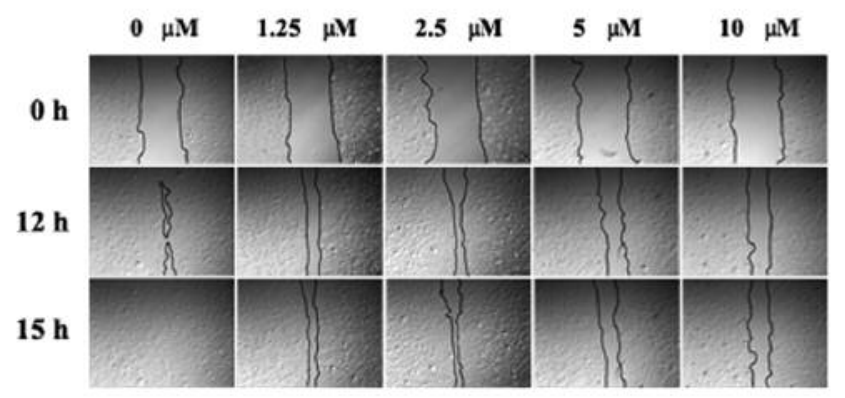

C

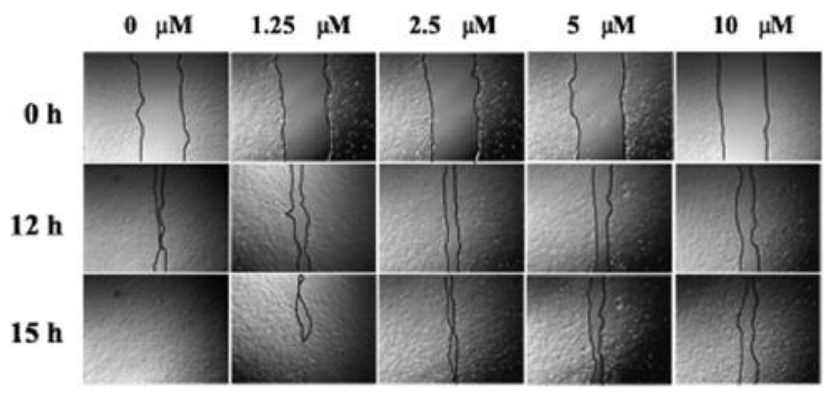

B

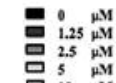

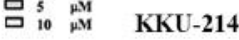
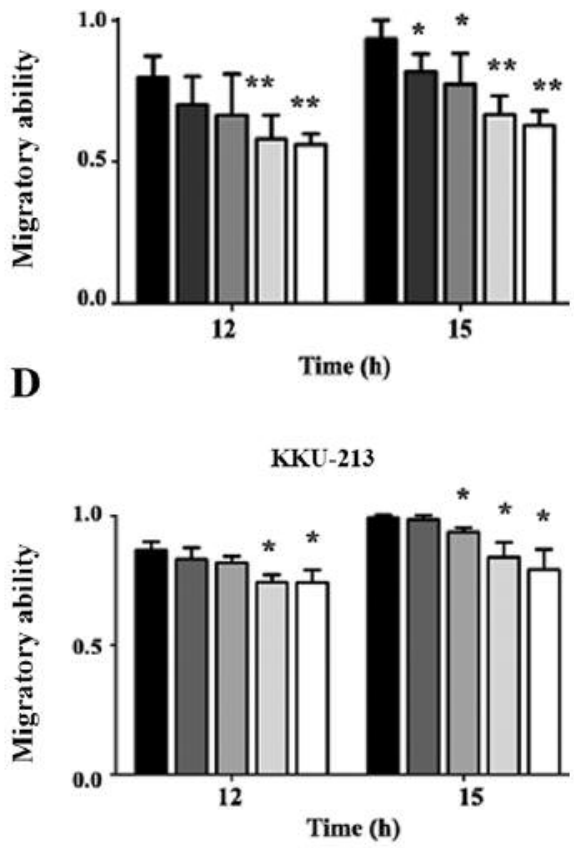

Figure 3. Migratory ability of $K K U-214(A, B)$ and $K K U-213(C, D)$ was examined in a wound-healing experiment. Cholangiocarcinoma cell lines were exposed to nimotuzumab at different concentrations and durations. Representative images of cell migration are shown ( $A, C)$ and data were quantified $(B, D)$. Significantly different at $* p<0.05$ and $* * p<0.01$ compared to the control by the Student's $t$-test.

with CCA. The expression of EGFR was analyzed using immunohistochemical staining. In the 94 cases of human CCA tissue, the expression of EGFR was high in $55 \%$ of patients with CCA. Representative examples of high and low expression of EGFR are shown in Figure 1A. Interestingly, high expression of EGFR was significantly correlated with shorter survival of patients with CCA $(p<0.01)$ (Figure 1B).

Growth-inhibitory effect of nimotuzumab on CCA cell lines. EGFR is a growth factor receptor that is involved in many cellular processes including cell growth. Therefore, we evaluated whether nimotuzumab inhibits CCA cell growth. Two cell lines (KKU-214 and KKU-213) were treated with nimotuzumab. The effect of nimotuzumab was investigated by SRB assay. The results show that nimotuzumab inhibited CCA cell growth in a dose- and time-dependent manner. Nimotuzumab at $10 \mu \mathrm{M}$ significantly reduced CCA cell growth at $96 \mathrm{~h}(p<0.05)$ compared to the control. Moreover, $20 \mu \mathrm{M}$ of nimotuzumab significantly reduced CCA cell growth at 72 and $96 \mathrm{~h}(p<0.01)$ in both KKU-214 and KKU213 cell lines (Figure 2). Low concentrations of nimotuzumab did not affect CCA cell growth.
Nimotuzumab inhibits CCA cell migration. The effect of nimotuzumab on cell metastasis was investigated. The migratory ability of CCA cells was assayed using a woundhealing assay. CCA cells were treated at different concentrations of nimotuzumab. The result for KKU-214 cells showed that nimotuzumab significantly reduced CCA cell migration at 1.25 and $2.5 \mu \mathrm{M}(p<0.05)$ at $15 \mathrm{~h}$, whereas at 5 and $10 \mu \mathrm{M}$ it significantly reduced CCA cell migration at both 12 and $15 \mathrm{~h}(p<0.01)$ (Figure $3 \mathrm{~A}$ and $\mathrm{B}$ ). The result for KKU-213 cells showed that nimotuzumab significantly inhibited cell migration at 5 and $10 \mu \mathrm{M}$ at 12 and $15 \mathrm{~h}$ $(p<0.05)$ (Figure 3C and D), respectively.

Nimotuzumab inhibits CCA cell invasion. In addition to migration, invasion is also a process that helps cancer cell metastasis. Therefore, we evaluated the effect of nimotuzumab on CCA cell invasion. The number of invading cells was significantly reduced at $10 \mu \mathrm{M}$ in both KKU-214 $(p<0.01)$ (Figure 4A and B) and KKU-213 $(p<0.05)$ (Figure 4C and D).

Molecular mechanism by which nimotuzumab inhibits CCA cell metastasis. The result from functional assays showed 
A

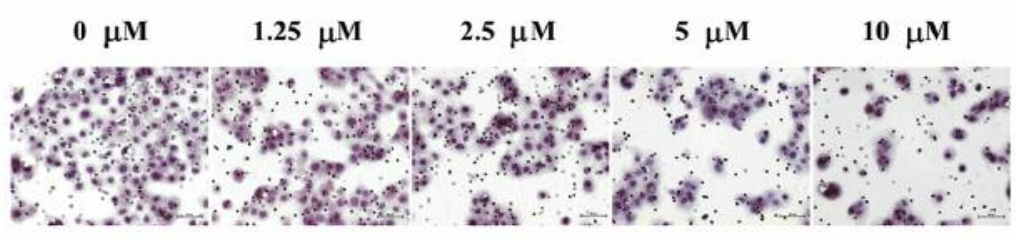

C

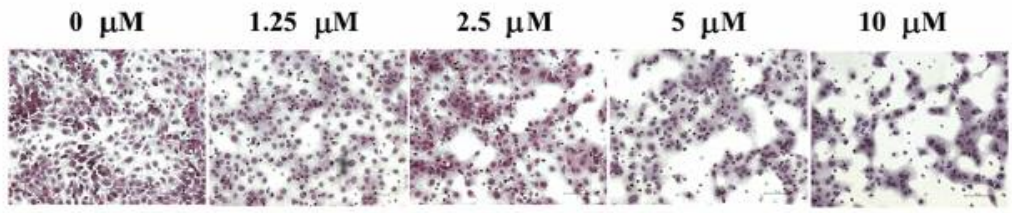

B

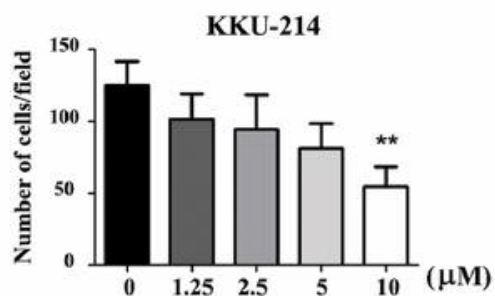

D

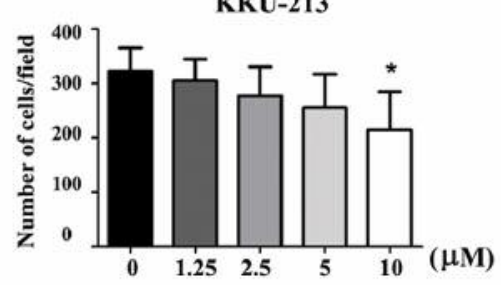

Figure 4. Invasive ability of KKU-214 (A, B) and KKU-213 (C, D) was determined using a Boyden chamber coated with Matrigel. Representative images of cell invasion are shown $(A, C)$ and data were quantified $(B, D)$. Significantly different at $* p<0.05$ and $* * p<0.01$ compared to the control by the Student's t-test.
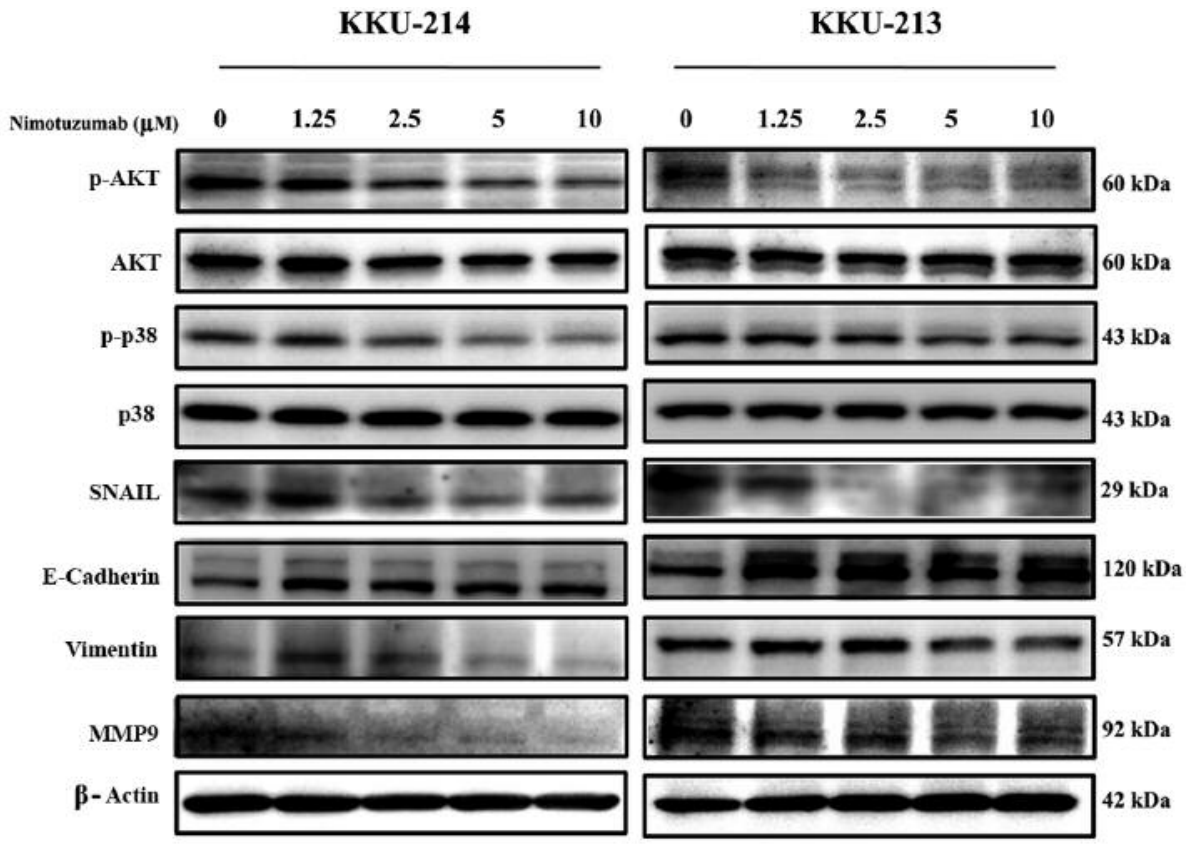

Figure 5. The molecular mechanism through which nimotuzumab inhibited metastasis of cholangiocarcinoma (CCA) cells. The images show the expression of proteins in nimotuzumab-treated CCA cells. Expression of phospho-protein kinase B (p-AKTser473), p-p38Thr180/Tyr182, zinc finger protein SNAII (SNAIL1), vimentin, and matrix metalloproteinase 9 (MMP9) were reduced, which that of E-cadherin increased in nimotuzumabtreated KKU-214 and KKU-213 cells. $\beta$-Actin was used as a loading control.

that nimotuzumab inhibited CCA cell metastasis. Therefore, a western blot assay was used to explore the molecular mechanism by which nimotuzumab achieves inhibition. The results showed nimotuzumab achieves this in KKU-214 and KKU-213 cells by inhibiting phosphorylation of AKT
$\left(\mathrm{p}-\mathrm{AKT}^{\mathrm{ser}}{ }^{273}\right)$ and $\mathrm{p} 38$ (p-p38 $\left.{ }^{\text {Thr180/Tyr182}}\right)$. Additionally, nimotuzumab inhibited the expression of SNAIL and vimentin, while inducing that of E-cadherin. Nimotuzumab also inhibited CCA cell invasion via reduction of MMP9 expression (Figure 5). 


\section{Discussion}

EGFR is a tyrosine kinase receptor that is involved in many cellular processes. Aberrant EGFR expression leads to cancer development and progression. Since aberrant EGFR has been widely reported in many cancer types (27), it is a promising target for cancer treatment. Therefore, in the present study we aimed to evaluate whether targeting EGFR could be of benefit for CCA treatment. We found that a high expression of EGFR was significantly associated with shorter survival, i.e. a poorer prognosis of patients with CCA. This is consistent with previous studies showing that high expression of EGFR was associated with poor outcome in patients with cancer $(11,13,14,28,29)$. Thus, EGFR could be of value as a target for CCA treatment.

Nimotuzumab is a monoclonal antibody that inhibits EGFR activity. It binds with moderate affinity to domain III, an extracellular domain of EGFR and blocks the binding of ligands. Nimotuzumab has less adverse effects than another anti-EGFR antibody, cetuximab $(30,31)$. Chong and coworkers recently demonstrated that nimotuzumab inhibited human glioma cell viability (21). Similarly, the present study showed that nimotuzumab also inhibited CCA growth.

Metastasis is associated with cancer cell progression and can be induced by the activation of EGFR (32). The epithelial-mesenchymal transition (EMT) is a process by which epithelial cancer cells shift their phenotype to that of mesenchymal cells, thereby aiding in cancer cell metastasis (33). To facilitate metastasis, cancer cells have to alter their cell-cell contact properties (34). In this study, we demonstrated that nimotuzumab suppressed CCA cell migration. Our finding is consistent with a previous study that showed that nimotuzumab inhibited migration of salivary adenoid cystic carcinoma cells (35). We then examined the molecular mechanism by which nimotuzumab inhibits CCA cell migration. The result showed that nimotuzumab downregulated the phosphorylation of AKT and p38, down-stream effectors of EGFR, resulting in a reduction of SNAIL, a transcriptional factor in the EMT process. This supports the finding of previous studies $(21,22,34)$. We further explored the expression of the EMT markers E-cadherin and vimentin. Nimotuzumab reduced the expression of vimentin and induced E-cadherin expression. This suggests that nimotuzumab inhibits CCA cells migration via suppression of the EMT process in accordance with a previous report (35). Moreover, we found that nimotuzumab also inhibited CCA cell invasion by reducing the expression of MMP9, which is consistent with a previous study (34).

In conclusion, we demonstrated the expression of EGFR and its clinical significance in CCA. We also explored the effect of nimotuzumab on CCA cell progression. Our findings suggest that nimotuzumab may inhibit CCA cell metastasis by reduction of the EMT process.

\section{Conflicts of Interest}

The Authors declared that there is no conflict of interest in regard to this study.

\section{Acknowledgements}

This work was supported by Invitation Research Grant (IN59331) and a Postgraduate Study Support Grant from the Faculty of Medicine, Khon Kaen University, allocated to SP. The grant from the Thailand Research Fund (Grant No. RSA5980013) and a grant from Khon Kaen University allocated to WL. We thank Professor Trevor N. Petney for editing the MS via the Publication Clinic KKU, Thailand. We are also grateful to Alliance Pharma Company Limited, Thailand for providing us with nimotuzumab to complete this work.

\section{References}

1 Sripa B and Pairojkul C: Cholangiocarcinoma lessons from Thailand. Curr Opin Gastroenterol 24: 349-356, 2008.

2 Blechacz BR and Gores GJ: Cholangiocarcinoma. Clin Liver Dis 12: 131-150, ix, 2008.

3 Khan SA, Thomas HC, Davidson BR and Taylor-Robinson SD: Cholangiocarcinoma. Lancet 366: 1303-1314, 2005.

4 Loilome W, Yongvanit P, Wongkham C, Tepsiri N, Sripa B, Sithithaworn P, Hanai S and Miwa M: Altered gene expression in Opisthorchis viverrini-associated cholangiocarcinoma in hamster model. Mol Carcinog 45: 279-287, 2006.

5 Loilome W, Juntana S, Namwat N, Bhudhisawasdi V, Puapairoj A, Sripa B, Miwa M, Saya H, Riggins GJ and Yongvanit P: PRKAR1A is overexpressed and represents a possible therapeutic target in human cholangiocarcinoma. Int $\mathrm{J}$ Cancer 129: 34-44, 2011.

6 Loilome W, Juntana S, Pinitsoontorn C, Namwat N, Tassaneeyakul W and Yongvanit P: Suppression of PRKAR1A expression enhances antiproliferative and apoptotic effects of protein kinase inhibitors and chemotherapeutic drugs on cholangiocarcinoma cells. Asian Pac J Cancer Prev 13 Suppl: 143-147, 2012.

7 Dokduang H, Juntana S, Techasen A, Namwat N, Yongvanit P, Khuntikeo N, Riggins GJ and Loilome W: Survey of activated kinase proteins reveals potential targets for cholangiocarcinoma treatment. Tumour Biol 34: 3519-3528, 2013.

8 Bianco R, Gelardi T, Damiano V, Ciardiello F and Tortora G: Rational bases for the development of EGFR inhibitors for cancer treatment. Int J Biochem Cell Biol 39: 1416-1431, 2007.

9 Lee J and Moon C: Current status of experimental therapeutics for head and neck cancer. Exp Biol Med 236: 375-389, 2011.

10 Cohen D, Lane B, Jin T, Magi-Galluzzi C, Finke J, Rini BI, Bukowski RM and Zhou M: The prognostic significance of epidermal growth factor receptor expression in clear-cell renal cell carcinoma a call for standardized methods for immunohistochemical evaluation. Clin Genitourin Cancer 5: 264-270, 2007.

11 Hanawa M, Suzuki S, Dobashi Y, Yamane T, Kono K, Enomoto $\mathrm{N}$ and Ooi A: EGFR protein overexpression and gene amplification in squamous cell carcinomas of the esophagus. Int J Cancer 118: 1173-1180, 2006. 
12 Ito Y, Takeda T, Sasaki Y, Sakon M, Yamada T, Ishiguro S, Imaoka $S$, Tsujimoto $M$, Higashiyama $S$, Monden $M$ and Matsuura N: Expression and clinical significance of the erbB family in intrahepatic cholangiocellular carcinoma. Pathol Res Pract 197: 95-100, 2001

13 Lee HJ, Seo AN, Kim EJ, Jang MH, Kim YJ, Kim JH, Kim SW, Ryu HS, Park IA, Im SA, Gong G, Jung KH, Kim HJ and Park SY: Prognostic and predictive values of EGFR overexpression and EGFR copy number alteration in HER2-positive breast cancer. Br J Cancer 112: 103-111, 2015.

14 Maiti GP, Mondal P, Mukherjee N, Ghosh A, Ghosh S, Dey S, Chakrabarty J, Roy A, Biswas J, Roychoudhury S and Panda CK: Overexpression of EGFR in head and neck squamous cell carcinoma is associated with inactivation of $S H 3 G L 2$ and CDC25A genes. PLoS One 8: e63440, 2013.

15 Ruano Y, Ribalta T, de Lope AR, Campos-Martin Y, Fiano C, Perez-Magan E, Hernandez-Moneo JL, Mollejo M and Melendez B: Worse outcome in primary glioblastoma multiforme with concurrent epidermal growth factor receptor and p53 alteration. Am J Clin Pathol 131: 257-263, 2009.

16 Schrevel M, Gorter A, Kolkman-Uljee SM, Trimbos JB, Fleuren GJ and Jordanova ES: Molecular mechanisms of epidermal growth factor receptor overexpression in patients with cervical cancer. Mod Pathol 24: 720-728, 2011.

17 Wang W, Zhang J, Zhan X, Lin T, Yang M, Hu J, Han B and Hu $\mathrm{S}$ : SOX4 is associated with poor prognosis in cholangiocarcinoma. Biochem Biophys Res Commun 452: 614-621, 2014.

18 Yang X, Wang W, Wang C, Wang L, Yang M, Qi M, Su H, Sun X, Liu Z, Zhang J, Qin X and Han B: Characterization of EGFR family gene aberrations in cholangiocarcinoma. Oncol Rep 32: 700-708, 2014.

19 Zhou Q, Gong Y, Huang F, Lin Q, Zeng B, Li Z and Chen R: Expression levels and significance of nuclear factor-kappaB and epidermal growth factor receptor in hepatolithiasis associated with intrahepatic cholangiocarcinoma. Dig Surg 30: 309-316, 2013.

20 Boland $\mathrm{W}$ and Bebb G: The emerging role of nimotuzumab in the treatment of non-small cell lung cancer. Biologics 4: 289298, 2010.

21 Chong DQ, Toh XY, Ho IA, Sia KC, Newman JP, Yulyana Y, Ng WH, Lai SH, Ho MM, Dinesh N, Tham CK and Lam PY: Combined treatment of nimotuzumab and rapamycin is effective against temozolomide-resistant human gliomas regardless of the EGFR mutation status. BMC Cancer 15: 255, 2015.

22 Nitta Y, Shimizu S, Shishido-Hara Y, Suzuki K, Shiokawa Y and Nagane M: Nimotuzumab enhances temozolomide-induced growth suppression of glioma cells expressing mutant EGFR in vivo. Cancer Med 5: 486-499, 2016.

23 Bhuvaneswari R, Ng QF, Thong PS and Soo KC: Nimotuzumab increases the antitumor effect of photodynamic therapy in an oral tumor model. Oncotarget 6: 13487-13505, 2015

24 Akashi Y, Okamoto I, Iwasa T, Yoshida T, Suzuki M, Hatashita E, Yamada Y, Satoh T, Fukuoka M, Ono K and Nakagawa K: Enhancement of the antitumor activity of ionising radiation by nimotuzumab, a humanised monoclonal antibody to the epidermal growth factor receptor, in non-small cell lung cancer cell lines of differing epidermal growth factor receptor status. $\mathrm{Br}$ J Cancer 98: 749-755, 2008.

25 Rodriguez M, Perez L, Gavilondo JV, Garrido G, BequetRomero M, Hernandez I, Huerta V, Cabrera G, Perez M, Ramos O, Leyva R, Leon M, Ramos PL, Triguero A, Hernandez A,
Sanchez B, Ayala M, Soto J, Gonzalez E, Mendoza O, Tiel K and Pujol M: Comparative in vitro and experimental in vivo studies of the anti-epidermal growth factor receptor antibody nimotuzumab and its aglycosylated form produced in transgenic tobacco plants. Plant Biotechnol J 11: 53-65, 2013.

26 Namwat N, Puetkasichonpasutha J, Loilome W, Yongvanit P, Techasen A, Puapairoj A, Sripa B, Tassaneeyakul W, Khuntikeo $\mathrm{N}$ and Wongkham S: Downregulation of reversion-inducingcysteine-rich protein with Kazal motifs (RECK) is associated with enhanced expression of matrix metalloproteinases and cholangiocarcinoma metastases. J Gastroenterol 46: 664-675, 2011.

27 Harari PM: Epidermal growth factor receptor inhibition strategies in oncology. Endocr Relat Cancer 11: 689-708, 2004.

28 Laimer K, Spizzo G, Gastl G, Obrist P, Brunhuber T, Fong D, Barbieri V, Jank S, Doppler W, Rasse M and Norer B: High EGFR expression predicts poor prognosis in patients with squamous cell carcinoma of the oral cavity and oropharynx: a TMA-based immunohistochemical analysis. Oral Oncol 43: 193198, 2007.

29 Selvaggi G, Novello S, Torri V, Leonardo E, De Giuli P, Borasio P, Mossetti C, Ardissone F, Lausi P and Scagliotti GV: Epidermal growth factor receptor overexpression correlates with a poor prognosis in completely resected non-small-cell lung cancer. Ann Oncol 15: 28-32, 2004.

30 Talavera A, Friemann R, Gomez-Puerta S, Martinez-Fleites C, Garrido G, Rabasa A, Lopez-Requena A, Pupo A, Johansen RF, Sanchez O, Krengel $U$ and Moreno E: Nimotuzumab, an antitumor antibody that targets the epidermal growth factor receptor, blocks ligand binding while permitting the active receptor conformation. Cancer Res 69: 5851-5859, 2009.

31 Perez R, Moreno E, Garrido G and Crombet T: EGFR-targeting as a biological therapy: understanding nimotuzumab's clinical effects. Cancers 3: 2014-2031, 2011.

32 Claperon A, Mergey M, Nguyen Ho-Bouldoires TH, Vignjevic D, Wendum D, Chretien Y, Merabtene F, Frazao A, Paradis V, Housset $\mathrm{C}$, Guedj $\mathrm{N}$ and Fouassier L: EGF/EGFR axis contributes to the progression of cholangiocarcinoma through the induction of an epithelial-mesenchymal transition. J Hepatol 61: 325-332, 2014.

33 Jakobsen KR, Demuth C, Sorensen BS and Nielsen AL: The role of epithelial to mesenchymal transition in resistance to epidermal growth factor receptor tyrosine kinase inhibitors in non-small cell lung cancer. Transl Lung Cancer Res 5: 172-182, 2016.

34 Huang Y, Yu T, Fu X, Chen J, Liu Y, Li C, Xia Y, Zhang Z and Li L: EGFR inhibition prevents in vitro tumor growth of salivary adenoid cystic carcinoma. BMC Cell Biol 14: 13, 2013.

35 Jiang Y, Ge XY, Liu SM, Zheng L, Huang MW, Shi Y, Fu J, Zhang JG and Li SL: Nimotuzumab suppresses epithelialmesenchymal transition and enhances apoptosis in lowdose UV-C treated salivary adenoid cystic carcinoma cell lines in vitro. Anticancer Drugs 25: 1052-1060, 2014. 